\title{
Ambivalências humanas e não humanas em "Meu tio o Iauaretê", de Guimarães Rosa
}

[ Human and non-human ambivalences in "Meu tio o Iauaretê", by Guimarães Rosa

\author{
Gustavo de Castro e Silva ${ }^{\mathrm{I}}$ \\ Vanessa Daniele de Moraes ${ }^{2}$
}

\begin{abstract}
RESUMO • Problematização dos limites humano/animal a partir do conto "Meu tio o Iauaretê" de Guimarães Rosa. Ao explorar a noção de limite e a análise de mitologias que abordam o humano/animal, pretendemos circunscrever a presença da cultura indígena latino-americana e dessa mitologia no conto de Rosa. Analisaremos a presença do imaginário do jaguar nessa cultura e, para tanto, utilizaremos uma metodologia descritiva e interpretativa. Nossas conclusões apontam para a superação e a ultrapassagem desses limites pelos personagens rosianos no conto em questão. P PALAVRAS-CHAVE - Humano; animal; mitologias; "Meu tio o Iauaretê”; Guimarães Rosa. · ABSTRACT .
\end{abstract}

Problematization of the human-animal limits from the short story "Meu tio o Iauaretê" by Guimarães Rosa. In exploring the notion of limit and the analysis of mythologies that approach the human-animal, we intend to circumscribe the presence of the Latin American indigenous culture and its mythology in the story of Rosa. We will analyze the presence of the jaguar imaginary in this culture and, for that, we will use a descriptive and interpretative methodology. Our conclusions point to overcoming these limits by the rosean characters, in the story in question. . KEYWORDS - Human; animal; mythologies; "Meu tio o Iauaretê"; Guimarães Rosa.

Recebido em I8 de outubro de 2018

Aprovado em I5 de janeiro de 2020

SILVA, Gustavo de Castro e; MORAES, Vanessa Daniele de. Ambivalências humanas e não humanas em “Meu tio o Iauaretê", de Guimarães Rosa. Revista do Instituto de Estudos Brasileiros, Brasil, n. 75, p. 36-52, abr. 2020.

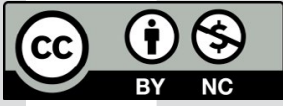

DOI: http://dx.doi.org/Io.II6o6/issn.23I6-90IX.voi75p36-52

I Universidade de Brasília (UnB, Brasília, DF, Brasil).

2 Universidade de Brasília (UnB, Brasília, DF, Brasil). 
Noções como domesticação e ferocidade, civilizado e selvagem, superioridade e inferioridade (racional e afetiva) são geralmente associadas aos limites do ser humano e do animal. Algumas dessas noções nos ajudarão aqui a pensar e a problematizar o conto "Meu tio o Iauaretê", de João Guimarães Rosa, que possui limites difusos, confusos e embaçados. A rejeição ao mundo "civilizado", feita pelo personagem de Rosa, abre caminhos para discutirmos questões relacionadas às fronteiras e aos limites entre um e outro. Para um pensamento para além das fronteiras, utilizaremos estudiosos que problematizam a necessidade de abertura epistemológica e disciplinar, como Cyrulnik (2007) e Morin (2002). Ambos pensam o afeto de distância e proximidade humano/animal a partir da crítica à visão antropológica e biológica, que nos define como "sapiens-sapiens" e não como "sapiens-demens".

Para discutir os afetos que problematizam a enrijecida "sapiência" humana, pretendemos desenvolver ideias de: Warburg (2008), que pensou esses limites a partir de sua experiência com os índios Pueblo, no Novo México, em I895, assim como seus rituais antropomórficos; Agamben (20I2), que observou a possibilidade da transcendência como passagem do humano ao espiritual; Galvão (I978) e Vélez Escallón (20I8), que pensaram o conto rosiano a partir da questão mitológica e da separação natureza e cultura. Esses autores questionam justamente até onde vão esses limites. Sabemos que Guimarães Rosa começou a se interessar pelo tema dos felinos e do imaginário do humano/animal quando visitou a região da Nhecolândia, no Pantanal mato-grossense, em I947. Naquela ocasião ele conversou e entrevistou caçadores de onças, os “zagaieiros”, que, com suas “azagaias" (lanças curtas e delgadas usadas como instrumento de caça), contaram seus feitos, lendas e experiências na relação com as onças. O escritor brasileiro conhecia as histórias acerca do jaguar, das onças e dos felinos no continente americano fosse pela experiência vivida em Mato Grosso, fosse no interesse pela cultura andina, nos anos em que morou em Bogotá (I942-I944), ou nas duas viagens que fez ao México, em I945 e I966. 


\section{A NOÇÃo DE “LIMITE”}

É bastante conhecido entre os estudiosos de Guimarães Rosa o seu amor à confecção de listas e à leitura de enciclopédias e dicionários. Esse amor está atestado na famosa entrevista concedida por Guimarães Rosa a Günter Lorenz, em I965, em que disse:

Hoje, um dicionário é ao mesmo tempo a melhor antologia lírica. Cada palavra é, segundo sua essência, um poema. Pense só em sua gênese. No dia em que completar cem anos, publicarei um livro, meu romance mais importante: um dicionário. Talvez um pouco antes. E este fará as vezes de minha autobiografia. (ROSA apud LORENZ, I973, p. 346).

Foi justamente esse apreço pela confecção de listas que levou o escritor mineiro a elaborar uma lista de sinônimos da palavra “limite”, no Caderno de Estudos I9, que possui 42 expressões, que reportamos a seguir:

Limite, linda, marca, linha, discrime, discrímen, confins, têrmo, enclave, fronteira, raia, arraia, fimento, afimento (aut.), contérmino, extrema, extremadela, extremidade, sêsmo (aut.), terminação, barreira, meta, risca, remate, término, órbita, baliza, marco, pinoco, cipó, colunelo, bões (= marcos de pedra), fradépio, mogo, padrão, piquêta, malhão, marco primordial, linha principal, linha divisória, linha divisora, linha demarcatória. (ROSA, s. d., p. 2I)3.

Seu interesse pela noção de limite pode ser reconhecido também mediante sua proximidade com o estudo da geografia; sua atividade profissional como chefe da Divisão de Fronteiras, do Ministério das Relações Exteriores entre I957 e I967; sua participação como membro efetivo e, depois, honorário, entre 1956 e I967, no Conselho de Geografia, do Instituto Brasileiro de Geografia e Estatística (IBGE) e seu particular interesse em explorar os limites da linguagem e do próprio pensamento mediante a metodologia do elenco e da catalogação. Pode ser também que seu interesse por tal palavra advenha justamente de sua atenção à noção de infinito ou Apeiron (de Perás = limite, perímetro + partícula "a" = sem), que é o termo grego para "indeterminado", "ilimitado" e "infinito". Rosa também sabia que os mitos permitem uma visão de finito e de infinito, de limite e de ilimitado, sabia que os mitos carregam consigo imagens cosmogônicas, permitem orientação e fixam os limites entre o profano e 0 sagrado, o limitado e o sem limites.

$\mathrm{O}$ escritor mineiro tinha em mente que transpor uma fronteira implicava mudança espacial, às vezes do íntimo e familiar para um horizonte diferente, um espaço estrangeiro, desconhecido, em que o risco e o confronto com o diferente prevaleciam. Como sabemos, uma das imagens de limite surge justamente na figura da divindade grega Hermes, descrito por Vernant (2009, p. 198) como aquele que possui "extensões sem rotas, das terras não cultivadas". A missão de Hermes é a de atravessar fronteiras, avançar rumo ao aberto. $O$ ser humano é feito de um interior e de um exterior, sendo que o interior é tranquilizador, cerrado, estável, e o exterior,

3 Foi mantida a grafia original. 
inquietante, aberto, móvel. Os gregos antigos, diz Vernant (2009, p. I98), expressaram isso na forma de duas divindades opostas e complementares: Héstia e Hermes. Héstia era a deusa do lar, senhora do coração da casa, sedentária, fechada sobre os humanos, personificava-se naquilo que era interior, fixo, delimitado, imóvel, com centro no grupo familiar, segurança face ao mundo exterior.

Hermes era nômade, vagabundo sempre a correr o mundo; passa sem cessar de um lugar a outro, rindo-se das fronteiras, das cercas, das portas, que ele transpõe por brincadeira, ao seu modo. Mestre das trocas, dos contatos, à espreita dos encontros, ele é o deus dos caminhos, onde guia o viajante, o deus também das extensões sem rotas, das terras não cultivadas, onde ele conduz os rebanhos, riqueza móvel. (VERNANT, 2009, p. I98).

Héstia e Hermes eram divindades que se opunham, mas que também eram indissociáveis. As oferendas dos viajantes estrangeiros, embaixadores, hóspedes vindos de longe, que cabiam ser ofertadas a Hermes eram, no entanto, depositadas nos altares de Héstia, como sinal de correspondência entre o interno e o externo. $\mathrm{O}$ ensinamento grego por detrás dessa prática era o de que, para que houvesse verdadeiramente um "interior", era preciso cuidar, reverenciar e reconhecer o "exterior", a fim de acolhê-lo.

Os pontos limítrofes entre os gregos congregavam um conjunto complexo de ideias que em sua maioria refletia uma dimensão do sagrado (SILVA, 20I6) e se baseava em três tipos de imagens que se completavam entre si: a natural, a humana e a imaginada. A primeira dessas imagens estava associada às características físicas do que era "humano" e "natural”. Não havia entre os gregos uma ideia de "natureza" ou de "humano", por exemplo, separada daquela de "sagrado". Ou seja, a experiência do sagrado era uma imersão extática na unidade da natureza. Aquilo que os gregos consideravam "humano" era algo segmentado e moldado pelas necessidades da agricultura e da organização política. Os "limites" do humano eram associados ao próprio mundo de Héstia, ou seja, o mundo da família, que se estendia até o limite dos oceanos. A paisagem mítica ou imaginada entre os gregos comportava a memória coletiva, os ritos, as percepções e experiências, que conformavam, por sua vez, os distintos modos de ver o mundo e suas construções. Entre os gregos, os mitos tornaram-se componentes essenciais na organização psicopolítica. Permitiam uma visão de finito e infinito, carregavam consigo imagens cosmogônicas, permitiam orientação e fixavam os limites do espaço profano e sagrado e entre Perás (finito) e Apeiron (infinito).

Associada à ideia de limite (Perás), encontra-se a palavra (Periodós), que pode ser, segundo Silva (20I6), entendida como invólucro, ou seja, aquilo que circunda e é capaz de separar o mundo ordenado do caos amorfo, o mundo estrangeiro do mundo conhecido, seja por meio de barreiras físicas impostas pela natureza ou por sanções divinas. O Periodós é um espaço organizado pelos deuses, uma hierofania, onde o sagrado é constantemente manifestado, fixando os limites e norteando o território habitável. O estabelecimento da noção de limites, no sentido de ordenamento de território, era essencial para a compreensão grega de cosmos. O espaço interno, aquele ocupado pelos seres humanos, era diferenciado do espaço externo, o território desconhecido, onde operava a noite e o caos. 
As regiões de fronteira pertenciam, por isso mesmo, aos deuses. Hora Metopia (em grego) era o espaço do "entre" ou da transição, geralmente associado à deusa Artemis, divindade, por sua vez, associada às áreas de disputa, àquilo que preside a passagem do selvagem ao civilizado, da infância à fase adulta, do cognoscível ao incognoscível. Estelas de pedras, marcos dispostos nos cimos de montanhas ou santuários eram utilizados, muitas vezes, como demarcadores de fronteiras, enfatizavam o "encontro" entre os territórios políticos, ponto entre mundos, ou seja, atuavam como limites entre o sagrado e o profano, entre o sensível e o transcendente, conectando, simultaneamente, Polis e Phisys. Essa mesma ideia fronteiriça também aparece para a demarcação do território geográfico em "Meu tio o Iauaretê”, de Guimarães Rosa: para explicar o motivo de sua solidão nos confins do sertão, o sobrinho do Iauaretê utiliza exemplos da paisagem natural. Lemos:

Acabei com as onças em três lugares. Da banda dali é o rio Sucuriú, vai entrar no rio Sorongo. Lá é sertão de mata virgem. Mas da banda de cá é o rio Ururáu, depois de vinte léguas é a Barra do Frade, já pode ter fazenda lá, pode ter gado. Matei as onças todas... Eh, aqui ninguém não pode morar, gente que não é eu. Eh, nhem? Ahã-hã... Casa tem nenhuma. Casa tem atrás dos buritis, seis léguas, no meio do brejo. (ROSA, I969, p. I3I).

Desejamos, contudo, neste artigo, enfatizar e problematizar não o "encontro" de territórios políticos e de paisagens naturais, mas o encontro entre as noções de humanidade e a de animalidade, e entender como elas atuam entre o sagrado e o profano, o sensível e o transcendente, conectando, simultaneamente, o interior e o exterior.

\section{As CONEXõES COM O MUNDO ANIMAL}

É possível pensar em humanidade e animalidade sem opor os dois conceitos? Até onde vai a pretensa soberania do homem sobre o animal? Warburg (2008) não considerava que o primeiro estivesse acima do segundo, numa escala valorativa. Quando permaneceu entre os índios Pueblo do Novo México e Arizona em sua juventude, observou um ritual de personificação animal: presenciou a dança do antílope em San Ildefonso, onde os índios colocavam uma máscara, dançavam e imitavam os antílopes. Nesse momento, eles se fundiam ao animal, ou seja, o ritual não era uma mera representação ou imitação, mas a própria integração humano/ animal. Warburg conclui:

Os índios pagãos, tanto quanto as outras culturas pagãs deste mundo, se conectam com o mundo animal - mediante aquilo que costumamos chamar de "totemismo" - impulsionados por um temor reverencial, sob a crença de que os animais de diferentes espécies são os ancestrais míticos de suas tribos. Sua explicação do mundo como uma formação de relações inorgânicas não se distancia tanto do darwinismo: enquanto nós classificamos uma lei natural ao processo autônomo da evolução, os pagãos buscam compreensões nas conexões com o mundo animal. (WARBURG, 2008, p. 30 - tradução livre). 
Entre as "conexões com o mundo animal", gostaríamos de pensar a separação homem-animal via afetos, sobretudo, a partir daquele afeto de proximidade que costumamos chamar de "amor". Segundo Morin (2002, p. I8), o amor tem origem na vida animal, um cão é gentil e afetuoso, muito mais do que o "animal-máquina" de Descartes, que simplesmente reage a estímulos. A afetividade se desenvolveu, segundo ele, entre mamíferos, como os cães. "Há, portanto, uma fonte animal incontestável no amor" (MORIN, 2002, p. I8). O afeto, por sua vez, tem relação direta com o calor nos mamíferos: do bebê que, quando nasce, chega ao impactante "mundo frio", aos animais de pelo "térmico", que procuram se aquecer junto à mãe ou aos irmãos. Esse calor se configura, mais tarde, nas relações afetuosas dos adultos mamíferos, que se concentram especialmente nos gestos da boca através da linguagem e do beijo:

Os mamíferos podem exprimir esta afetividade através do olhar, da boca, da língua, do som. Tudo aquilo que vem da boca já se torna algo que fala do amor, antes mesmo de qualquer linguagem: a mãe que lambe o filho, o cão que lambe a mão; esses fatos já exprimem o que vai aparecer e desenvolver-se no mundo humano: o beijo. Aqui reside o enraizamento animal e mamífero do amor. (MORIN, 2002, p. I9).

Mas o processo civilizatório distanciou bombasticamente nossa própria animalidade. Usou de artifícios prejudiciais à saúde em nome do progresso, nos afastou de nossos instintos. Um exemplo disso, é que, na Pré-História, o homem parecia agir instintivamente, como os animais, no tratamento das enfermidades: lambiam suas feridas, bebiam muita água e se aproximavam das fogueiras quando tinham febre. Cyrulnik (2007) chama a atenção para a mudança no comportamento dos cães a partir do pensamento ocidental. Nossa impregnação cultural modificou completamente o psiquismo deles, que antes tinham um comportamento mais selvagem (farejavam, caçavam) passando a agir como animais de estimação, dóceis, "civilizados", cães de guarda, supercães! $O$ autor atenta para o fato de que, mesmo que não sejam dotados de fala, seu comportamento parece imitar nossa linguagem humana:

Como todos os seres civilizados, eles latem muito, exprimindo assim sua participação em nossas trocas verbais. Contudo, se os cães pastores só latem com conhecimento de causa, os cães selvagens, por sua vez, pouco latem, pois todos os caçadores são calados, seja qual for sua espécie. (CYRUNIK, 2007, p. I).

Nesse sentido, estamos nos afastando de nossa animalidade, ao invés de nos reconciliarmos com ela. Por isso mesmo trazemos para o diálogo uma narrativa em que as relações entre os animais e os homens se configuram de uma nova maneira: 0 conto "Meu tio o Iauaretê", que integra a edição póstuma de Estas estórias, nos instiga a pensar em nossa natureza animal, que se emerge e transborda quando em contato com o meio selvagem. 


\section{“O IMPOSSÍVEL RETORNO”“4}

O sobrinho do Iauaretê, personagem-narrador que emblema o conto 5 de Guimarães Rosa, é a voz da narrativa. A identificação dele com as onças se mostra no comportamento, na linguagem e nos afetos. Não sabemos exatamente o que diz o seu interlocutor, apenas inferimos essa identificação pela fala do narrador. O sobrinho do Iauaretê, ou Tonho Tigreiro $^{6}$, como é chamado por alguns, era um agregado de fazendeiro que tinha a tarefa de "desonçar" o sertão, mas "vai gradativamente rejeitando o civilizado e se reconhecendo no animal. Acaba preferindo onças a homens, acaba virando onça e matando homens" (GALVÃO, I978, p. I5). Nota-se que é um sertanejo que não esconde seu parentesco com as onças, sobretudo quando passa a se arrepender de ter caçado muitas delas: "Mecê não pode falar que eu matei onça, pode não. Eu, posso. Não fala, não. Eu não mato mais onça, mato não. É feio - que eu matei. Onça meu parente" (ROSA, I969, p. I29). O conto vai revelando que não somente há um parentesco entre esse homem e as onças, como também a própria personagem vai se revelando um felino: gosta de onça e se comporta como uma; conhece cada uma daquelas que habitam os "gerais": onça, jaguar, canguçu, pintada, pinima, malha-larga, jaguaretê, jaguaretê-pixuna, pixuna, maçaroca, suassurana e tigre.

Num hibridismo do fantástico com o real, conseguimos captar a linguagem do sertanejo, das onças e do indígena ${ }^{7}$, e vemos um desfecho trágico: ao demonstrar ao seu interlocutor que está se transformando em onça ou mesmo retornando ao estado de onça, ele o amedronta cada vez mais. O epílogo dá margens para a interpretação de que ele pode ter sido fuzilado ou para o fato de ter atacado o interlocutor ao se metamorfosear em onça. A narrativa é feita aos goles de cachaça e com onomatopeias magníficas, mesclando o falar sertanejo aos grunhidos. É o momento em que

4 Esse é o título de um ensaio de Walnice Nogueira Galvão que faz parte de seu livro Mitológica rosiana (I978).

5 Narrativa que foi deixada pronta por João Guimarães Rosa antes de falecer. Esse conto foi reunido junto com outros oito que ele preparou e publicado postumamente pela Editora José Olympio (que posteriormente passou os direitos autorais para a editora Nova Fronteira). A primeira edição de Estas estórias é de 1969, mas Byron Vélez Escallón (20I8, p. 293) lembra a publicação prévia na revista Senhor em I96I e que Rosa também já havia anotado ter concluído esse conto em I949, logo após o episódio conhecido como "Bogotazo", na Colômbia.

6 Esse personagem/narrador afirma não ter mais nome, embora tenha sido nomeado de Bacuriquipera pela mãe e de Tonico pelo pai, além de alguns apelidos, como Macuncôzo ou Tonho Tigreiro. "Agora tenho nome mais não...” (ROSA, I969, p. I44).

7 Eduardo Viveiros de Castro, no artigo “Os involuntários da Pátria” (20I7) explica a diferença entre "índio" e "indígena". O primeiro termo refere-se aos membros e comunidades conscientes "de sua relação histórica com os indígenas que viviam nesta terra antes da chegada dos europeus”; receberam essa nomeação porque os desbravadores achavam que haviam chegado às Îndias. Já a palavra "indígena", mais antiga, significa "gerado dentro da terra que lhe é própria, originário da terra em que vive" (VIVEIROS DE CASTRO, 20I7, p. 3). 
a linguagem se desarticula, tornando-se grunhidos, que o interlocutor percebe a metamorfose e lhe aponta a arma. Galvão observou:

[...] longe de ser mera estória de lobisomem ou fábula de licantropia, éuma profunda reflexão sobre natureza e cultura [...]. Trata-se de um texto literário ímpar, como fina percepção do que é tragédia da extinção de culturas, que ocorreu e ainda ocorre extensamente neste nosso continente americano, do Ártico à Antártida. (GALVÃO, I978, p. I9).

Dentro da ideia de interferências culturais, "o cru se torna ou cozido, por mediação da cultura, ou podre por mediação da natureza” (GALVÃO, I978, p. I8). Interessante perceber, pelas vias antropológicas, que o domínio do cru (natural, sem aculturamento, pré-fogo) atrai o narrador para suas origens. Ele deixa para trás seu perfil dominador, o de caçador de onças (território do cozido, do aculturamento pelo homem branco) para optar pelo cru (a sua natureza animal, sem a dominação "cultural"). No entanto, a personagem transita nas fronteiras entre um e outro, especialmente quando nos é revelado o elemento "fogo": o fogo que simboliza sua cachaça, o fogo da arma que o mata.

A personagem rosiana, ao que parece, não está se metamorfoseando num bicho ou “se animalizando"; ela já demonstra, desde o início de "sua prosa”, ser um bicho do mato. Acontece então um reconhecimento, a personagem se identifica com aqueles felinos, seus parentes, como se fosse um animal mesmo, e, essa, a sua origem. Iauaretê é um nome de onça, e isso significa que o narrador é sobrinho de jaguar, jaguaretê. Ou filho, noutra leitura, pois, no tupi, o irmão da mãe é o pai, como percebe Galvão (I978, p. I9). Em sua busca, ela vai descobrindo parentescos que explicam uma genealogia bastante convincente. Observa, por exemplo, as repetidas afirmações do narrador sobre a onça ser de sua família e também quando ele diz "ser" onça, já que seu tio Jaguaretê é irmão de sua mãe:

Ou, sendo tutira em tupi o tio irmão da mãe, as afirmações apontam para um parentesco classificatório matrilinear, onde, no nosso código, os tios irmãos da mãe são pais, mas no código do narrador os pais são tios. [...] o título Meu tio o Iauaretê, sintética e admiravelmente, propõe o branco, o índio e a onça misturados, tal como no texto se misturam o português, o tupi e o animal dos resmungos e rugidos. Ao mesmo tempo afirma: não pertenço à raça branca de meu pai, pertenço ao clã tribal de minha mãe, cujo totem é a onça. A onça, sendo totem do clã tribal de minha mãe, é meu ancestral, meu antepassado, minha origem; e a ele regresso, à onça, defraudado senhor-do-fogo. (GALVÃO, I978, p. 2I).

Observem os termos usados por Galvão: ancestral; antepassado; origem; regresso. Concordamos com eles para pensar que o narrador não "se transforma em onça”, mas "retorna" à sua origem. A autora destaca, ainda, outras relações homem-animal pelo viés dos mitos e cultos ancestrais e aponta:

Na região do atual México, dentre a infinidade de povos que ali se misturaram durante milênios, uma das culturas mais antigas é a do povo-jaguar, os Olmeca da Fase La Venta. As representações em pedra mostram figuras antropomórficas, cujos rostos misturam aos humanos traços felinos: boca arreganhada, caninos salientes, olhos 
repuxados, nariz achatado e sobrancelhas flamíferas. Esse povo tem no jaguar o seu ancestral; nasceram da cópula entre uma mulher e um jaguar, de que resultou um bebê-jaguar. (GALVÃO, I978, p. I4).

La Venta, no estado de Tabasco, e San Lorenzo, estado de Vera Cruz - ambas as regiões no México -, contam com os maiores registros nesse tipo de escultura olmeca. Tais civilizações, no entanto, tiveram fim com uma catástrofe que destruiu os monumentos. Os olmecas representavam animais, com suas esculturas, sendo o maior deles o o jaguar, visto como um deus. Consideravam-no sinônimo de beleza e faziam com que os bebês que nasciam já tomassem a forma do animal, achatando suas cabeças, lixando os dentes para que ficassem pontiagudos, cortando o lábio superior da criança. Levya (20I8, p. 28 - tradução livre) pontua: "Esse tipo de pensamento também foi herdado às culturas pré-hispânicas posteriores nas quais é comum a imagem do nahual, um ser metade homem metade animal, que tem muitos poderes mágicos e protetores".

Sabe-se que a cultura olmeca foi depois absorvida por outras culturas, como os zapotecas de Oaxaca e, em seguida, os maias. Para os olmecas algumas estátuas representam seres sobrenaturais - a maioria com partes humanas e feições de animais. Na região chamada Potrero Nuevo encontram-se estátuas em mau estado de conservação, como a de uma mulher, de costas, e, sobre ela, um jaguar, como se os dois estivessem copulando. $\mathrm{O}$ jaguar era considerado o deus mais poderoso das culturas pré-hispânicas, e a águia era o animal preferido das culturas posteriores, que enfrentaram os espanhóis. A disputa entre os dois foi inevitável: "Em algum momento, quando os velhos povos desafiaram os novos, teve lugar uma disputa entre jaguares e águias" (LEVYA, 20I8, p. 37 - tradução livre).

Para a leitura do conto de Rosa, Galvão (I978) teceu ligações mitológicas entre o leão, a onça, o tigre em vários registros espalhados pela América, sobretudo, no México. Ela se recorda do Popol Vuh, o códice maia que escapou à queima dos conquistadores das Américas e que consta de vários registros de felinos misturando-se aos homens. Em algumas imagens nas pedras, tigres cravam as patas num homem e retiram seu coração. Esse imaginário chega ao Brasil, como sabemos, sobretudo no folclore e nas Cavalhadas ${ }^{8}$. Lembrando o relato de Warburg, no início deste trabalho, percebemos muitas semelhanças entre os ritos antropomórficos do México e algumas manifestações brasileiras.

8 Essa festa de Goiás, de origem ibérica, aparentemente não teria por que usar um animal americano em suas indumentárias. Mas a Cavalhada (ritual que representa os conflitos entre cristãos e mouros) é interpretada por Carlos Rodrigues Brandão como um conflito “que se dá no mundo humano, se reconcilia no nível sobrenatural, sendo indispensável para essa reconciliação que o ‘espião mouro', usando pele e máscara de onça e imitando seus modos, como representante da natureza seja inicialmente eliminado, e a tiros de armas de fogo" (apud GALVÃO, I978, p. I6). 


\section{JAGUARETÊ E JURUPARI}

Além da região do México, vemos indícios do jaguar sendo venerado em outros lugares. O Museo del Oro, em Bogotá (Colômbia), traz representações dos felinos na região de San Agustín, por exemplo, que datam do primeiro milênio depois de Cristo. Os povos dessa região faziam esculturas em pedras para reverenciar o homem-jaguar.

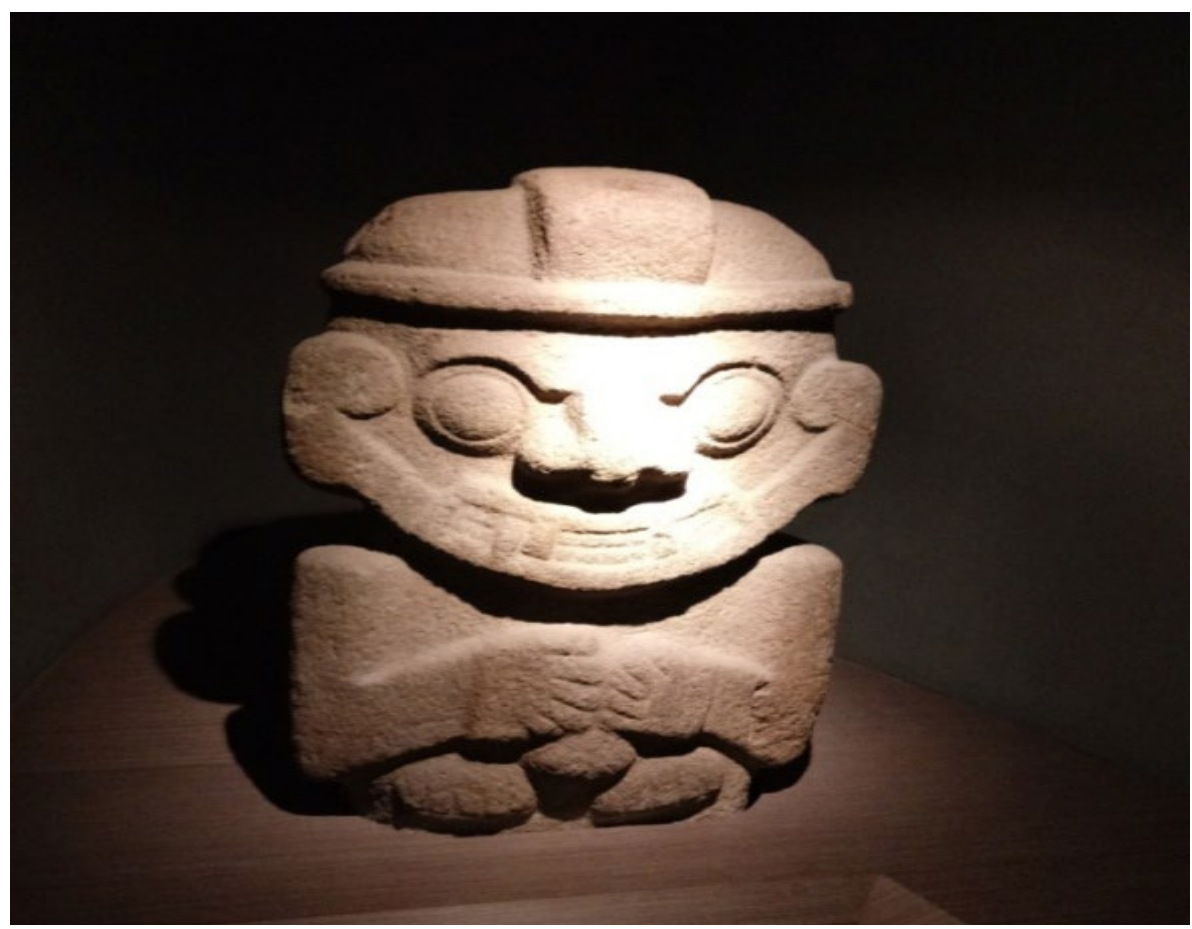

Figura I - Escultura de San Agustín. Museo del Oro

(Bogotá), junho de 20I8 - arquivo pessoal

O museu também informa que o jaguar foi um símbolo associado ao poder e à religião na América de tempos antigos. Em suas paredes, lemos:

Evidências materiais e textos revelam que personagens de alto nível tinham nomes alusivos a felinos, utilizavam atavios elaborados com suas peles, pintavam manchas em seus corpos e levavam caudas e unhas grandes. Nesses tempos, se guardavam seus crânios enquanto ferozes imagens felinas se faziam de guardiães?

De modo semelhante ao ritual presenciado por Warburg no México, as crônicas colombianas narram que caciques e sacerdotes se transformavam em "grandes gatos”, comunicando-se com outros espíritos de jaguar durante a cerimônia. Além dos rituais, viam na escultura uma maneira de imortalizar sua imagem e seu poder.

9 Escritos fotografados no Museu del Oro, Bogotá (Colômbia) em I3/6/20I8 (tradução livre). 
Recorriam, assim, a escultores, que deixavam os trabalhos sobre pedras vulcânicas, sempre simbolizando homens e mulheres ornamentados com as distinções de seu clã para diferenciar seu poder diante da comunidade.

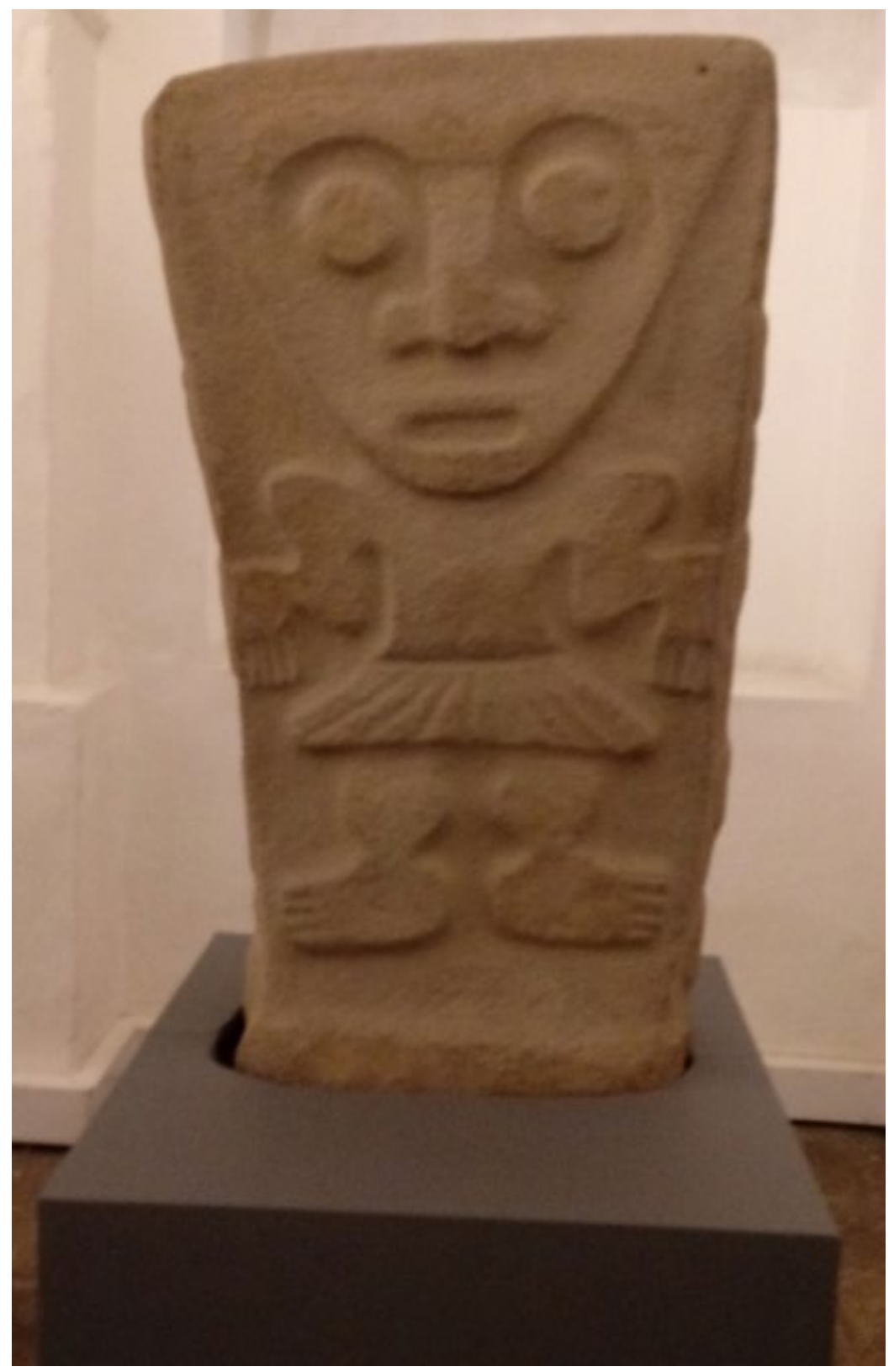

Figura 2 - Figura antropomorfa. Região arqueológica de San Agustín, Huila (Colômbia). I-9oo d.C. Pedra polida e talhada 


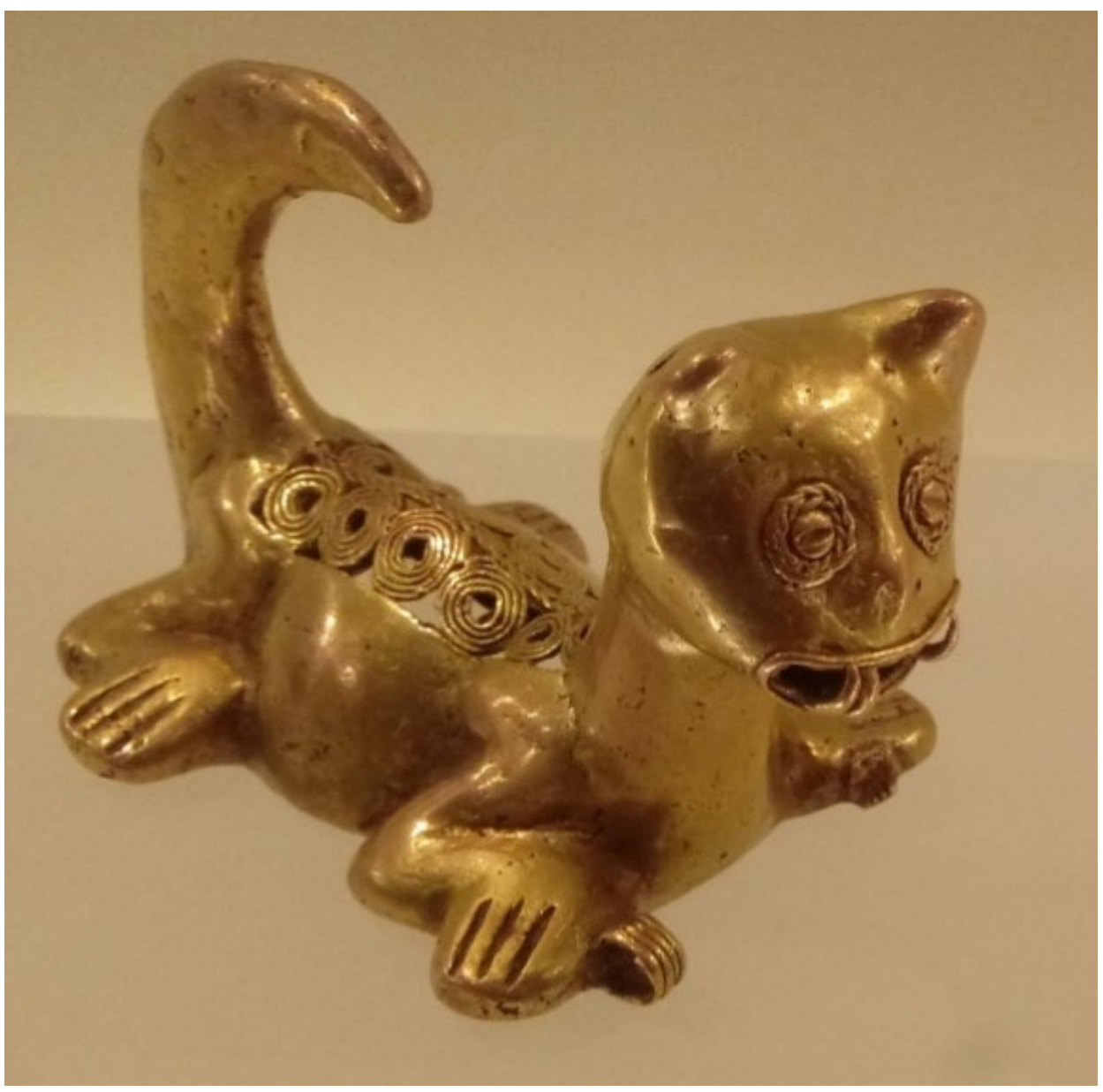

Figura 3 - Pingente jaguar. El banco Magdalena, 350 d.C.

A narrativa de João Guimarães Rosa não se distancia desses mitos e narrativas advindos do período anterior à colonização da América, até mesmo quando pensamos nos disfarces, na consciência do homem em querer agir como felino - no caso, a onça. O personagem revela logo no início do conto: "Cê tem medo? Mecê, então, não pode ser onça... Cê não pode entender onça. Cê pode? Fala! Eu aguento calor, guento frio" e, numa outra passagem: "Só sei o que onça sabe" (ROSA, I969, p. I28; p. I33).

Num dos mitos coletados na Colômbia, temos que o tigre era humano, era pajé. Vestia-se de tigre e atacava os homens de outro clã, assim como atacava as jovens antes da puberdade, fazendo carícias nelas com sua cauda. Diz a lenda, ainda, que, quando se disfarçava de tigre, pedia que o chamassem pelo nome de homem para que não o matassem por engano. Um homem não o chamou, e, então, o mataram ${ }^{\text {Io }}$. Análoga a essa lenda, da bacia do Uaupés também pode ter saído a ideia para o conto

Io Esse fragmento encontra-se na parede do Museo Del Oro, mas foi extraído dos mitos da etnia desana. Os índios que aí vivem estão na fronteira do Brasil com a Colômbia, à margem do rio Uaupés (tradução livre). 
de Guimarães Rosa, como chama a atenção Vélez Escallón (20I8). Ele atenta para o fato de que a narrativa de Yuruparý pode ter dado origem ao Iauaretê, inclusive se pensarmos nas nomenclaturas:

Os nomes Yavaraté e Iauaretê são transliterações diferentes da mesma palavra ñe’engatú, a mesma língua yeral que o índio Maximiano José Roberto (que era parcialmente Tariano) usara na sua versão da Lenda de Jurupari, posteriormente traduzida ao italiano e publicada pelo explorador Ermanno Stradelli em I890. (VÉLEZ ESCALLÓN, 20I8, p. 287).

Jurupari, nas contribuições ao conto do Iauaretê, se destaca também por sua lei musical (músicas secretas, destinadas a homens, onde a interdição tem a morte como punição), que, dentre os instrumentos, tem-se o iasmeserené ou jaguar, em língua tariana. A concepção da figura de Jurupari acontece através da fecundação do suco de uma fruta, phiycan. Seu caráter é ambíguo: fasto e nefasto, animal e divino, vegetal e humano, de acordo com Vélez Escallón (20I8, p. 287). Ambiguidade ${ }^{\text {II }}$ que também é marcada na fala de Castro (20I5) acerca do mito de Jurupari, pois a dualidade contribui com os rastros da formação do imaginário do povo brasileiro. A visão de que somos "ou isso ou aquilo", e não "isso e aquilo", também foi reforçada com a imposição do pensamento do homem branco quando em contato com os indígenas. Quando os primeiros jesuítas chegaram ao Brasil, empenharam-se em classificar os deuses dos povos que aqui viviam; identificaram que os povos e os pajés adoravam, entre outros, uma divindade chamada "Jurupari” - ser complexo, contraditório e temerário: "Em uma cabeça que pensa de forma binária (bem e mal, por exemplo) só pode haver forças opostas, deus versus demônio” (CASTRO, 20I5).

Vélez Escallón (20I8) aponta para o conhecimento de Rosa sobre a lenda de Jurupari por sua erudição, poliglotismo e, sobretudo, pelo fato de Rosa ter sido chefe do Serviço Brasileiro de Demarcação de Fronteiras. O mito de Jurupari teve muita difusão e versões diferentes. Vélez Escallón observa no conto de Rosa sete pecados capitais, impostos pelos cristãos no processo de aculturamento do índio, que ditam as regras para que o sobrinho do Iauaretê os matasse (ou desejasse matar). O narrador diz não matar por dinheiro, mas sim porque, para ele, são todos “doentes”. E as doenças percebidas por Vélez Escallón são os próprios pecados, que ele enumera: I) gula - Preto Bijibo; 2) ira - Seo Rioporo; 3) preguiça - Jababora Gugué; 4) avareza Jababora Antunias; 5) inveja - Preto Tiodoro; 6) luxúria - Maria Quirineia (perdoada); 7) soberba - Veredeiro seo Rauremiro e família. Fecha-se, assim, um ciclo de assassinatos provocados pela não aceitação dos pecados alheios. Essas motivações são derivadas, justamente, a partir da catequização do branco sobre os índios - a "doença do progresso", ou ainda "a própria voragem civilizatória que impõe domesticação a tudo que não conhece através de tudo o que exclui” (VÉLEZ ESCALLÓN, 20I8, p. 3I9).

II A canção de Caetano Veloso intitulada "Tigresa" (do álbum Bicho, lançado em I977) vai apontando características de uma felina e destacando as ambiguidades presentes na mulher pela qual o eu-lírico se encantou. Dentre tantas dualidades encontradas na letra, essa se destaca: "me falou que o mal é bom e o bem cruel". 


\section{A alma da gente e dos bichos}

Agamben (20I2, p. 9) nos conta sobre a existência de uma bíblia hebraica do século XIII que contém, dentre outras imagens, um banquete em mesa farta no qual os justos não são representados com cabeças humanas, e sim com cabeças de animais. Não se sabe ao certo o motivo dessas representações, mas ele aposta nos estudos de Sofia Ameisenowa, pesquisadora que tentou aplicar os métodos de Warburg aos materiais judaicos. Nessa concepção:

[...] as imagens dos justos com feições animais deveriam reportar-se ao tema gnóstico-astrológico da representação dos decanos teromórficos, através da doutrina gnóstica segundo a qual os corpos dos justos (ou melhor, dos espirituais), reascendendo após a morte em direção aos céus, transformam-se em estrelas e identificam-se com as potências que governam cada céu. (AGAMBEN, 20I2, p. IO-II).

As estreitas relações humano/animal vão sendo explicadas de acordo com a tradição rabínica, em que os justos esperam, ainda vivo, o Messias. Nos textos maniqueus consta que esses arcontes estão representados pelas cinco partes do reino animal: os bípedes, os quadrúpedes, os pássaros, os peixes e os répteis, "de tal forma que a representação teromórfica dos arcontes remete diretamente para o tenebroso parentesco entre macrocosmo animal e microcosmo humano" (AGAMBEN, 2OI2, p. II).

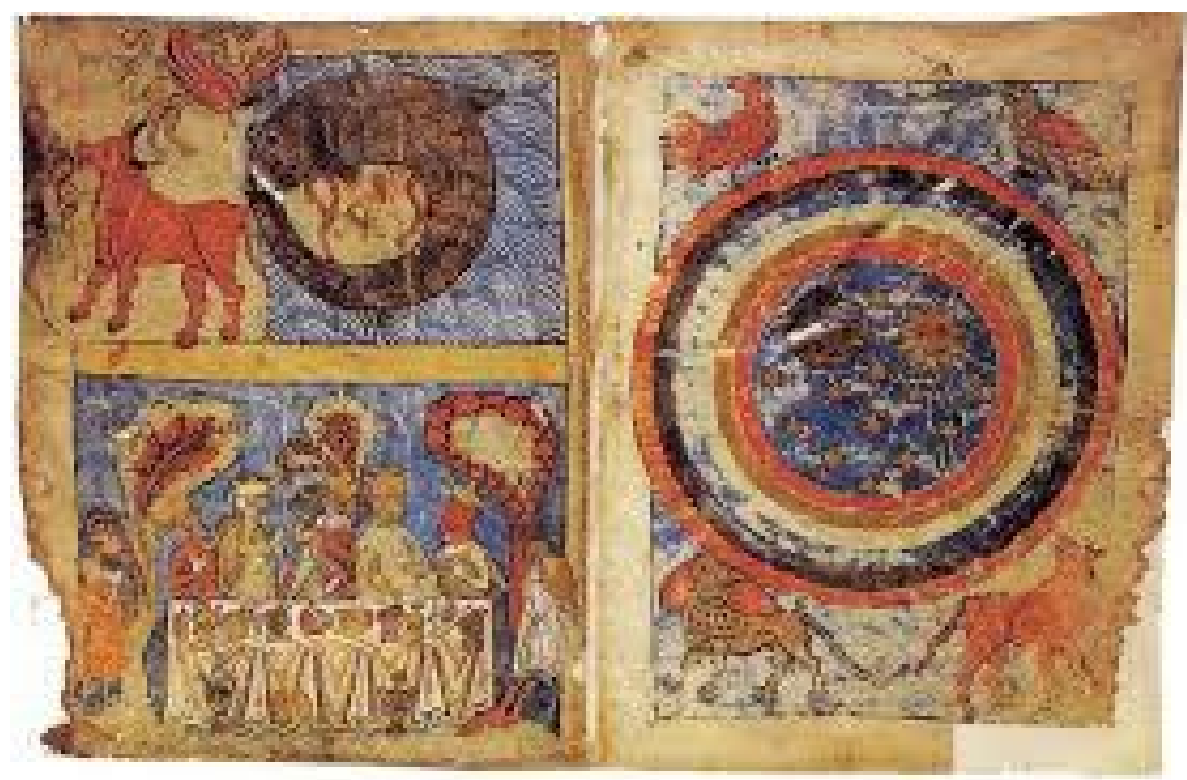

Figura 4 - Bíblia hebraica do século XIII: a visão de Ezequiel; os três animais das origens; o banquete messiânico dos justos (AGAMBEN, 20I2, p. 6)

Para Agamben, a vida é algo que não se conceitua e, por isso mesmo, deve ser 
articulada e dividida. Tal articulação, para ele, tem um ponto crítico: Aristóteles, no De anima separa declaradamente o animal daquilo que não tem vida: é através do viver que o animal se distingue do inanimado. Na visão aristotélica, muitas coisas podem ter vida (o pensamento, o movimento e a sensação, por exemplo), mas nem todas têm alma. A partir dos pressupostos de Bichat ${ }^{\mathrm{T} 2}$, Agamben assinala a importância desses conhecimentos, uma vez que, num procedimento cirúrgico moderno com anestesia, por exemplo, o que está em jogo é a possibilidade de separar esses “dois animais" e depois de religá-los. Para ele, a biopolítica, iniciada no século XVII e muito analisada por Michel Foucault, traria questionamentos essenciais para o conceito de vida vegetativa. Ainda hoje a questão da eutanásia é muito polêmica e o Estado intervém com suas próprias leis sobre a continuação (ou não) de vidas que não apresentam mais atividade cerebral, além da tão polêmica questão da descriminalização do aborto. O filósofo italiano propõe que pensemos no "homem como aquilo que resulta da desconexão destes dois elementos" (AGAMBEN, 20I2, p. 29); e que investiguemos o que é o homem diante dessas divisões; que pensemos como foi separado dos outros seres (não tomando posição, mas refletindo sobre esse "afastamento"). A sua intuição diz que até as relações com o divino dependem, de algum modo, da esfera mais obscura (aquela que nos separa do animal).

\section{ConClusões}

O encontro entre as noções de humanidade e de animalidade em "Meu tio o Iauaretê" nos ajuda a questionar os limites do civilizado e do selvagem, além da suposta superioridade racional e afetiva do ser humano sobre os animais. O ser-jaguar ou a volta ao estado originário ("de onça") flerta também com os limites do que seria o sagrado e o profano, o sensível e o transcendente, ultrapassando e conectando, simultaneamente, o interior ao exterior, o humano ao animal. A nosso ver, o sobrinho do Iauaretê nunca foi totalmente civilizado, nem totalmente selvagem, existe nele uma latência humano/ animal que não se separa, mas, ao contrário, retroalimenta sua dupla condição.

Entendemos que a separação humano/animal não deve ser pensada estritamente como oposição racional versus não racional. A partir da noção de "demens", devemos pressupor que a loucura faz parte do humano, é necessária: traz consigo o ódio, a crueldade, a barbárie e a cegueira. Morin (2002, p. 7) diz que "o ser humano é um animal insuficiente, não apenas na razão, mas é também dotado de desrazão”. $O$ que existe é a tentativa de controle do homo demens para que sobressaia o racional. Inibimos o demens para não deixar que o nosso lado homicida se revele, assim como nossas maldades e nossas imbecilidades. Morin reconhece os limites da razão e propõe que pensemos no hibridismo humano/animal. O conto de Rosa está impregnado de mitologia latino-americana, seja a do jaguar das civilizações andinas,

I2 Marie François Xavier Bichat (I77I-I802) estudaria a constituição tecidual dos órgãos através do método físico-químico, fazendo a distinção entre vida animal e vida orgânica. Bichat postulava que cada organismo humano possuía dois tipos de animais - o interior (o orgânico: circulação de sangue, fezes, excreções e assimilações) e o "literalmente" animal - o exterior (a vida na relação com o mundo, com o social). 
seja a de Jurupari, seja a do Pantanal mato-grossense. O sobrinho do Iauaretê, que não é nem humano, nem animal, assume as duas condições ao mesmo tempo, semelhante a Jurupari, que possui o arquétipo do bem e do mal. Animais e homens não precisam se excluir, são seres duplos, nos quais ora sobressai o sapiens, ora o demens. As mitologias mesmo são capazes de juntar esses fragmentos todos sem conclusões, pois não há polaridades nessas narrativas - elas se ligam em algum momento, se transformam, se ampliam. São ambíguas. Nesse sentido, as narrativas dos felinos encontradas nas regiões de San Agustín, os rituais vivenciados por Warburg exaltando a personificação dos antílopes, os mitos olmecas e o conto rosiano não se excluem, mas se complementam.

\section{SOBRE OS AUTORES}

GUSTAVO DE CASTRO E SILVA é professor de Estética da Comunicação da Faculdade de Comunicação da Universidade de Brasília (FAC/UnB) e autor de $O$ enigma Orides (Hedra, 20I5).

E-mail: gustavodecastro@unb.br https://orcid.org/o0oo-oooI-7I26-6947

VANESSA DANIELE DE MORAES é doutora pelo Programa de Pós-Graduação em Comunicação da FAC/UnB, integrante do Grupo de Pesquisa em Comunicação e Produção Literária (Siruiz) e autora de Passagens abjetas (Papa-livro, 20II). E-mail: quantasvanessas@gmail.com https://orcid.org/oooo-0o02-2368-2337

\section{REFERÊNCIAS}

AGAMBEN, Giorgio. O aberto: o homem e o animal. Tradução André Dias e Ana Bigotte Vieira. Lisboa: Edições 70, 2012.

CAMARGO, Frederico Antonio Camillo. Da montanha de minério ao metal raro: os estudos para obra de João Guimarães Rosa. Dissertação (Mestrado em Letras). Departamento de Teoria Literária e Literatura Comparada, Faculdade de Filosofia, Letras e Ciências Humanas, Universidade de São Paulo, 2013.

CASTRO, Gustavo. A imaginação no Brasil: estética, mitologia e senso de transcendência. Conferência na Escola Internacional de Arte, Literatura e Som na Cultura da Imagem Contemporânea, Sorbonne. Colóquio FAC/UnB, dezembro, 2015.

CYRULNIK, Boris. Os alimentos afetivos: o amor que nos cura. Tradução Cláudia Berliner. 2. ed. São Paulo: Martins Fontes, 2007. 
GALVÃO, Walnice Nogueira. Mitológica rosiana. São Paulo: Ática, I978.

LEVYA, José Mariano. Olmecas, zapotecos y mixtecos: los indígenas de Mesoamérica IV. Ilustraciones de Aleida Ocegueda. Ciudad de México: Nostra Ediciones, 2018.

LORENZ, Günter W. Diálogo com a América Latina: panorama de uma literatura do futuro. São Paulo: EPU, I973.

MORIN, Edgar. Amor, poesia, sabedoria. 4. ed. Rio de Janeiro: Bertrand Brasil, 2002.

MUSEO DEL ORO. Exposição Permanente. Bogotá - Colômbia, junho de 2018.

ROSA, João Guimarães. Caderno de Estudos I9. Manuscrito. Fundo João Guimarães Rosa, IEB/USP, código de referência JGR-CADERNO-I9, s. d.

. Meu tio o Iauaretê. In: . Estas estórias. Nota introdutória de Paulo Rónai. Capa de Poty. Rio de Janeiro: José Olympio Editora, I969, p. I26-I59.

SILVA, Sued Ferreira da. A natureza da paisagem entre os gregos. Revista Paranoá: cadernos de arquitetura e urbanismo, n. I6, 20I6, p. I75-I82.

VÉLEZ ESCALLÓN, Byron Oswaldo. Do tamanho do mundo: o Páramo de Guimarães Rosa - com um Yavaratê. Pittsburgh: Instituto Internacional de Literatura Iberoamericana, 2018.

VELOSO, Caetano. Tigresa. Bicho. Gravadora Philips, I977, vinil, duração: 6:2I’.

VERNANT, Jean-Pierre. A travessia das fronteiras. Trad. Mary Amazonas Leite de Barros. São Paulo: Edusp, 2009.

VIVEIROS DE CASTRO, Eduardo. Os involuntários da Pátria: elogio do subdesenvolvimento. Caderno de Leituras, n. 65, Série Intempestiva, maio de 2017.

WARBURG, Aby. El ritual de la serpiente. Traducción de Joaquín Etorena Homaeche. Madrid: Editorial Sexto Piso, 2008. 